\title{
PEGARUH STRUKTUR AKTIVA DAN PERTUMBUHAN PENJUALAN TERHADAP STRUKTUR MODAL
}

\author{
Hermaya Ompusunggu \\ Universitas Putera Batam \\ email: hermaya@puterabatam.ac.id
}

\begin{abstract}
The purpose of this research is to exemine the effect of asset structure and sales growth to the capital structure. The data in this research is the secondary data by using financial statement data. The population in this research were companies which are listed in the Indonesia Stock Exchange with the mining sector from 2014 to 2018. The sample collection technique has been done by using purposive sampling and 8 (eight) companies which meet the criteria have been selected as the research samples. The measurement of capital structure has been done by Debt to Equity Ratio (DER). The analysis has been done by using multiple linear regression. The result of the research shows the partial regression analysis is asset structure significant effect on capital structure with significance 0,317 >0,05 and sales growth significant effect on capital structure with significance 0,039<0,05. While the results obtained simultaneously variable asset structure and sales growth significantly influence capital structure with significance $0,039<0,05$.
\end{abstract}

Keywords: Asset Structure, Sales Growth and Capital Structure.

\section{PENDAHULUAN}

Pada era globalisasi sekarang ini ditandai dengan banyak bermunculnya usaha-usaha baru. Dalam dunia usaha yang berkembang semakin pesat ini menyebabkan pertumbuhan ekonomi menjadi tinggi. Sehingga timbul persaingan yang semakin tajam dan kompetitif dalam dunia usaha. Menghadapi persaingan tersebut, perusahaan dituntut untuk mampu memciptakan atau meningkatkan nilai perusahaan serta mampu untuk mengelola faktor-faktor produksi yang ada secara efektif dan efesien agar tujuan perusahaan mampu untuk memperoleh laba yang maksimal dan optimal. Dalam hal ini, perusahaan juga dituntut untuk mampu menentukan kinerja perusahaan yang baik, sehingga perusahaan akan dapat menjamin kelangsungan hidupnya.

Pada dasarnya setiap perusahaan membutuhkan modal untuk membiayai kegiatan operasional dan pengembangan bisnisnya sehingga modal menjadi salah satu elemen yang penting dalam perusahaan. Semakin besar modal yang dimiliki perusahaan maka semakin pula kegiatan operasional yang dapat dilakukan. Sumber perdanaan atau modal di dalam suatu perusahaan dibagi ke dalam dua kategori yaitu perdanaan internal berupa modal sendiri yang diperoleh dari sumber laba ditahan dan perdanaan eksternal berupa modal pinjaman yang diperoleh dari para kreditor atau yang disebut dengan hutang dari pemilik, peserta atau pengambil bagian dalam perusahaan yang disebut modal, proporsi atau bauran dari penggunaan modal sendiri dan htang dalam memenuhi kebutuhan dana perusahaan disebut struktur modal perusahaan. Struktur modal adalah perimbangan atau perbandingan antara hutang dan modal sendiri (Maulia, 2015). Keputusan dalam pemilihan sumber dana merupakan hal yang penting karena hal tersebut akan memperngaruhi struktur modal perusahaan yang akhirnya mempengaruhi kinerja keuangan. Umumnya perusahaan cenderung untuk mengguakan modal internal sebagai modal permanent, sedangkan modal eksternal hanya digunakan sebagai pelengkap saja apabila dana yang dibuthkan kurang mencukupi. Untuk itu penetapan struktur modal suatu perusahaan perlu dipertimbangkan sebagai variable yang mempengaruhinya.

Struktur modal yang optimal merupakan struktur modal yang diperkirakan biaya modal rata-rata tertimbang yang paling rendah yang diharapkan dapat meningkatkan nilai perusahaan. 
Kebijakan struktur modal dipengaruhi oleh bermacam-macam faktor baik dari luar perusahaan, seperti kondisi pasar modal, tingkat bunga, stabilitas politik maupun faktor internal. Penentuan struktur modal sedikit banyak akan dipengaruhi oleh faktor internal perusahaan. Faktor internal diantaranya profitabilitas, pembayaran dividen, ukuran perusahaan, stabilitas penjualan, struktur aktiva, operating leverage, tingkat pertumbuhan, pengendalian dan sikap manajemen. Pada umumnya perusahaan yang besar memiliki profitabilitas tinggi, memiliki stabilitas penjualan yang bagus atau tingkat pertumbuhan yang tinggi cendurung tidak Struktur modal yang optimal merupakan struktur modal yang diperkirakan biaya modal rata-rata tertimbang yang paling rendah yang diharapkan dapat meningkatkan nilai perusahaan. Kebijakan struktur modal dipengaruhi oleh bermacam-macam faktor baik dari luar perusahaan, seperti kondisi pasar modal, tingkat bunga, stabilitas politik maupun faktor internal. Penentuan struktur modal sedikit banyak akan dipengaruhi oleh faktor internal perusahaan. Faktor internal diantaranya profitabilitas, pembayaran dividen, ukuran perusahaan, stabilitas penjualan, struktur aktiva, operating leverage, tingkat pertumbuhan, pengendalian dan sikap manajemen. Pada umumnya perusahaan yang besar memiliki profitabilitas tinggi, memiliki stabilitas penjualan yang bagus atau tingkat terlalu banyak membutuhkan dana dari pihak luar karena mereka memiliki sumber dana dari dalam berupa laba yang cukup besar.

Struktur aktiva merupakan perbandingan antara aktiva tetap dengan total aktiva yang dimiliki perusahaan yang dapat menentukan besarnya alokasi dana untuk masing-masing komponen aktiva (Nudzunul, 2015). Semakin tinggi struktur aktiva perusahaan menunjukkan semakin tinggi kemampuan perusahaan mendapatkan jaminan hutang jangka panjang. Perusahaan dengan struktur aktiva tinggi cenderung memilih menggunakan dana dari pihak luar atau hutang untuk mendanai kebutuhan modalnya. Sedangkan perusahaan yang berukuran besar memiliki kemampuan dan fleksibilitas yang lebih untuk mengakses sumber dana eksternal sehingga cenderung meningkatkan hutang. Hal itu terjadi karena kreditur lebih tertarik pada perusahaan besar dibanding perusahaan kecil sebab pinjaman dari kreditur membutuhkan jaminan setimpal dengan jumlah yang dipinjamkan pada perusahaan.

Penjualan merupakan salah satu faktor penting yang menentukan kelangsungan hidup perusahaan. Perusahaan mendapatkan dana untuk kelangsungan hidup dan berkembang selain hutang dan modal sendiri, juga dari penjualan produk perusahaan baik berupa barang maupun jasa. Manajemen perusahaan berusaha dapat meningkatkan penjualan produknya karena pertumbuhan penjualan yang tinggi dan stabil saling berkaitan dengan keuntungan perusahaan.

Pertumbuhan penjualan perusahaan mengindikasikan kemampuan perusahaan dalam mempertahankan kelangsungan usahanya. Perusahaan yang memiliki tingkat pertumbuhan penjualan yang tinggi akan membutuhkan lebih banyak investasi pada berbagai elemen aktiva, baik aktiva tetap maupun aktiva lancar. Perusahaan yang memiliki tingkat pertumbuhan penjualan yang tinggi akan mampu memenuhi kewajiban finansialnya seandainya perusahaan tersebut membelanjai aktivanya dengan hutang, begitu pula sebaliknya.

Dengan melihat laporan keuangan yang terdapat di Bursa Efek Indonesia selama beberapa tahun ini dimana data struktur aktiva, pertumbuhan penjualan dan struktur modal dari tahun ke tahun mengalami fluktuasi pada Tabel 1.1 pada perusahaan di bawah ini:

Tabel 1.1

Daftar Data Struktur Aktiva, Pertumbuhan Penjualan dan Struktur Modal (Debt to Equity Ratio) pada Perusahaan Pertambangan yang terdaftar di Bursa Efek Indonesia tahun 2014-2018

\begin{tabular}{|c|c|c|c|c|c|c|}
\hline Nama & \multicolumn{2}{|c|}{ Indo Tambangraya Megah Tbk } & \multicolumn{3}{c|}{ Toba Bara Sejahtera Tbk } \\
\hline Tahun & $\begin{array}{c}\text { Struktur } \\
\text { Aktiva }\end{array}$ & $\begin{array}{c}\text { Pertumbuhan } \\
\text { Penjualan }\end{array}$ & DER & $\begin{array}{c}\text { Struktur } \\
\text { Aktiva }\end{array}$ & $\begin{array}{c}\text { Pertumbuhan } \\
\text { Penjualan }\end{array}$ & DER \\
\hline
\end{tabular}




\begin{tabular}{|c|c|c|c|c|c|c|}
\hline 2014 & $23,82 \%$ & $45,83 \%$ & $45,05 \%$ & $14,00 \%$ & $81,24 \%$ & $280,98 \%$ \\
\hline 2015 & $25,50 \%$ & $3,40 \%$ & $46,76 \%$ & $13,02 \%$ & $-20,37 \%$ & $135,73 \%$ \\
\hline 2016 & $26,86 \%$ & $-12,67 \%$ & $47,67 \%$ & $15,73 \%$ & $6,34 \%$ & $138,85 \%$ \\
\hline 2017 & $26,80 \%$ & $-12,84 \%$ & $48,14 \%$ & $15,93 \%$ & $18,52 \%$ & $111,87 \%$ \\
\hline 2018 & $24,61 \%$ & $-17,18 \%$ & $42,20 \%$ & $17,30 \%$ & $-30,26 \%$ & $82,04 \%$ \\
\hline
\end{tabular}

Sumber : Data olahan penulis, 2019.

Dari tabel 1.1 terlihat DER dari tahun 2014-2018 untuk beberapa perusahaan terjadi fluktuasi yang disebabkan oleh struktur aktiva dan pertumbuhan penjualan. Struktur modal tergantung dari banyaknya sumber daya yang diperoleh internal perusahaan maupun eksternal berupa modal sendiri dan hutang. Faktor-faktor yang mempengaruhi struktur aktiva dan pertumbuhan penjualan antara lain pertumbuhan ekonomi, kondisi politik yang tidak stabil dan kebijakan pemerintahan.

Dari berbagai faktor tersebut diduga sebagai penyebab tinggi rendahnya tingkat struktur modal atau DER perusahaan sedangkan yang diharapkan struktur modal yang optimal. Maka sebagai alternatif solusinya adalah mengatur struktur aktiva yang mengoptimalkan aktiva tetap dan tingkat pertumbuhan penjualan akan banyak menggunakan hutang jangka panjang daripada modal sendiri.

Untuk menghindari terlalu meluasnya permasalahan yang akan diteliti maka hanya dibatasi pada factor internal yang mempengaruhi struktur modal berupa struktur aktiva dan pertumbuhan penjualan. Objek yang diteliti yaitu perusahaan pertambangan yang terdaftar di Bursa Efek Indonesia periode 2014-2018. Artikel ini bertujuan untuk mengetahui bagaimana pengaruh struktur aktiva, dan pertumbuhan penjualan terhadap struktur modal pada perusahaan pertambangan yang terdaftar di BEI periode 2014-2018.

\section{TINJAUAN PUSTAKA}

\section{Struktur Modal}

Menurut Suad Husnan (2009:1.3-1.6), manajemen keuangan menyangkut kegiatan perencanaan, analisis dan pengendalian kegiatan keuangan. Mereka yang melaksanakan kegiatan tersebut sering disebut manajer keuangan. Manajer keuangan harus mengambil keputusan tentang: Pengunaan dana disebut sebagai keputusan investasi., Memperoleh dana disebut sebagai keputusan perdanaanPembagian laba disebut kebijakan dividen. Keputusan investasi akan tercermin pada sisi aktiva perusahaan. Dengan demikian, akan mempengaruhi struktur kekayaan perusahaan, yaitu perbandingan antara aktiva lancar dengan aktiva tetap. Sebaliknya, keputusan perdanaan dan kebijakan dividen akan tercermin pada sisi pasiva perusahaan. Apabila kita hanya memperhatikan dana yang tertanam dalam jangka waktu yang lama perbandingan disebut sebagai struktur modal. Apabila diperhatikan baik dana jangka pendek maupun dana jangka panjang, perbandingannya disebut sebagai struktur finansial. Keputusan perdanaan dan kebijakan dividen mempengaruhi kedua struktur tersebut.

\section{Struktur Aktiva}

Menurut Brigham dan Houtsan (2001) dalam penelitian Gusti (2013) menyatakan bahwa suatu perusahaan dengan aktiva yang bisa dijadikan jaminan hutang dapat menggunakan hutang lebih besar. Struktur asset perusahaan memiliki pengaruh positif terhadap kebijakan hutang perusahaan terutama bagi perusahaan yang memiliki aktiva tetap dalam jumlah yang besar. Aktiva 
tersebut dapat dijadikan sebagai jaminan oleh manajer kepada kreditor sehingga manajer dapat memperoleh pinjaman dengan mudah. Struktur aktiva juga mempengaruhi fleksibilitas perusahaan dalam menentukan alternatif perdanaan eksternal karena dianggap memiliki tingkat risiko kebangkrutan relatif kecil daripada rasio aktiva tetap yang rendah. Menurut Syamsudin (2009) dalam penelitian Nudzunul (2015), struktur aktiva merupakan penentuan berapa besar alokasi dana untuk masing-masing komponen aktiva, baik aktiva lancar maupun aktiva tetap.

\section{Pertumbuhan Penjualan}

Rasio pertumbuhan (Growth Ratio) merupakan rasio yang menggambarkan kemampuan perusahaan dalam mempertahankan posisi ekonominya di tengah pertumbuhan perekonomian dan sektor usahanya. Dalam rasio pertumbuhan yang dianalisis adalah pertumbuhan penjualan, laba bersih, pendapatan per saham dan dividen per saham (Kasmir, 2015:114-115).

Menurut Kesuma (2009) dalam Nudzunul (2015) menyatakan bahwa pertumbuhan penjualan adalah perhitungan kenaikan dan penurunan penjualan perusahaan dari tahun ke tahun. Perusahaan dengan penjualan relatif stabil dapat lebih aman memperoleh lebih banyak pinjaman dan menanggung beban tetap yang lebih tinggi dibanding perusahaan yang penjualannya tidak stabil. Perusahaan-perusahaan yang mempunyai tingkat pertumbuhan lebih cepat, akan membutuhkan dana dari sumber eksternal yang lebih besar (Brigham dan Houtsan 2011 dalam Gusti 2013).

\section{Kerangka Konseptual}

Kerangka konseptual dapat digambarkan seperti dibawah ini:

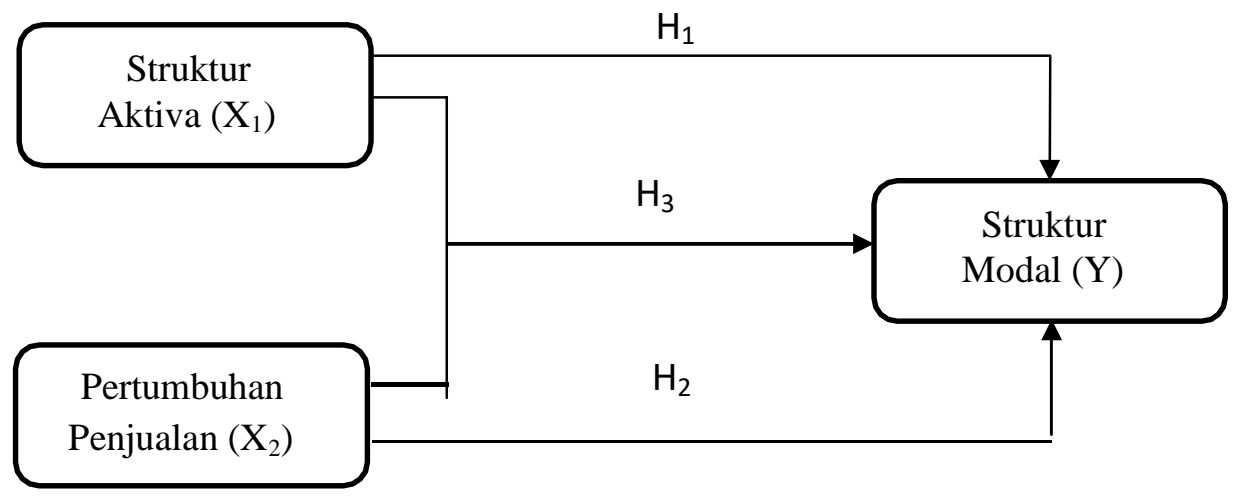

\section{Gambar 2.1 Kerangka Konseptual}

\section{Hipotesis Penelitian}

Berdasarkan kerangka konseptual diatas, maka hipotesis untuk penelitian ini dirumuskan sebagai berikut:

$\mathrm{Ha}_{1}$ : Terdapat pengaruh signifikan struktur aktiva terhadap struktur modal.

$\mathrm{Ha}_{2}$ : Terdapat pengaruh signifikan pertumbuhan penjualan terhadap struktur modal.

$\mathrm{Ha}_{3}$ : Terdapat pengaruh signifikan struktur aktiva pertumbuhan penjualan terhadap struktur modal.

\section{METODE}

Penelitian yang bersifat kuantitatif asosiatif, sebab dalam penelitian ini penulis ingin menggali lebih jauh keefektivitasan pengaruh ataupun juga hubungan antara satu variabel dengan variabel lainnya. Maka untuk mendeskripsikannya digunakan beberapa rumus statistik, sehingga penelitian ini dikenal dengan penelitian kuantitatif. Jenis data yang digunakan dalam penelitian ini adalah jenis data sekunder yang bersifat data kuantitatif. Data kuantitatif adalah data yang 
berupa angka. Sesuai bentuknya data kuantitatif dapat diolah atau dianalisis dengan menggunakan teknik perhitungan statistik (Syofian Siregar, 2013).

Sesuai dengan pokok masalah hipotesis yang akan diuji, maka variabel penelitian yang akan diuji meliputi:

(a) Variabel Dependen (Y)

Variabel dependen yang digunakan dalam penelitian ini adalah Struktur Modal (Debt to Equity Ratio/ DER). Rasio DER menunjukkan perbandingan antara hutang dengan modal sendiri (Suad Husnan, 2010).

Debt to Equity Ratio dapat dirumuskan sebagai berikut:

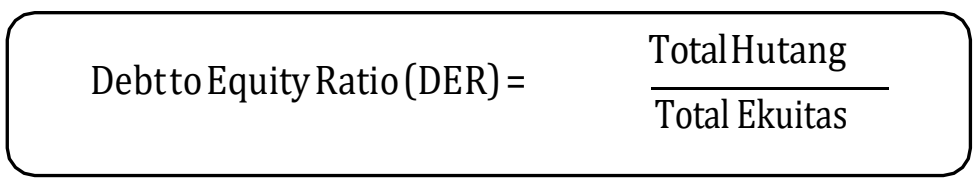

a. $\quad$ Variabel Independen $(\mathrm{X})$

Dalam penelitian ini yang menjadi variabel independen antara lain:

1. Struktur Aktiva

Struktur aktiva merupakan perbandingan antara aktiva tetap dengan total aktiva yang digunakan sebagai penentuan seberapa besar alokasi dana untuk masing-masing komponen aktiva. Aktiva yang dimaksud adalah aktiva yang berhubungan dengan struktur modal perusahaan, terutama aktiva tetap.

Perhitungan struktur aktiva merujuk pada penelitian Trisna (2010) yaitu:

\begin{tabular}{|c|c|}
\hline \multirow{2}{*}{ StrukturAktiva= } & AktivaTetap \\
\hline & Total Aktiva \\
\hline
\end{tabular}

2. Pertumbuhan Penjualan

Pertumbuhan penjualan adalah perhitungan kenaikan dan penurunan penjualan perusahaan dari tahun ke tahun. Perusahaan- perusahaan yang mempunyai tingkat pertumbuhan lebih cepat, akan membutuhkan dana dari sumber eksternal yang lebih besar.

Perhitungan pertumbuhan penjualan merujuk pada penelitian Gusti (2013) yaitu:

$$
\text { SalesGrowt } h=\frac{\text { Salest }- \text { Salest }-1}{\text { Salest }-1}
$$

Keterangan :

Sales Growth $=$ Petumbuhan Penjualan

Sales $\mathrm{t} \quad=$ Penjualan tahun sekarang

Sales $\mathrm{t}-1 \quad=$ Penjualan tahun sebelumnya

Metode pengambilan sampel dalam penelitian ini dilakukan dengan purposive sampling . Metode pengumpulan data dengan menggunakan studi Pustaka dan metode dokumentasi. Metode analisis data dengan menggunakan Teknik analisis data secara statistic dengan menggunakan program SPSS ( Statistical Package forSocial Science) versi 25. Teknik analisis yang digunakan dalam penelitian ini adalah: Statistik Deskriptif yang bertujuan untuk menguji hipotesis ( pertanyaan sementara) dari penelitian yang bersifat deskriptif. Penerapan jenis statistik untuk 
penelitian yang bersifat deskriptif sangat tergantung dari skala pengukurannya seperti nominal, ordinal dan interval/rasio. Selain uji statistic deskriptif analisis data juga menggunakan ujiasumdi klasik yeng meliputi uji normalitas, Multikolonieritas, Heteroskedastisitas dan Uji Autokorelasi. Model Regresi Berganda menurut Syofian Siregar (2013: 301), berganda adalah pengembangan dari regresi linier sederhana, yaitu sama-sama alat yang digunakan untuk memprediksi permintaan di masa akan datang berdasarakan data masa lalu atau untuk mengetahui pengaruh satu atau lebih variabel bebas (independent) terhadap satu variabel tak bebas (dependent) yang digunakan. Perbedaan penerapan metode ini hanya terletak pada jumlah variabel bebas (independent) yang digunakan. Penerapan metode regresi berganda jumlah variabel bebas (independent) yang digunakan lebih dari satu yang mempengaruhi satu variabel tak bebas (dependent).

Rumus Regresi Linier Berganda:

$$
\begin{aligned}
& Y=a+b_{1} X_{1}+b_{2} X_{2}+b_{3} X_{3} \ldots+b_{n} X_{n} \\
& \text { Di mana: } \quad \mathrm{Y} \quad=\text { Variabel terikat, } \\
& \mathrm{X}_{1} \quad=\text { Variabel bebas pertama } \\
& \mathrm{X}_{2} \quad=\text { Variabel bebas kedua, } \\
& \mathrm{X}_{3}=\text { Variabel bebas ketiga, } \\
& X_{n} \quad=\text { Variabel bebas ke- } n \text {, } \\
& \mathrm{a}, \mathrm{b}_{1} \text { dan } \mathrm{b}_{2}=\text { konstanta. }
\end{aligned}
$$

\section{Pengujian Hipotesis}

\section{a. Uji Koefisien Determinasi $\left(\mathbf{R}^{2}\right)$}

Koefisien determinasi pada intinya untuk mengatur seberapa jauh kemampuan model dalam menerangkan variasi variabel dependen. Nilai koefisien determinasi adalah 0 dan 1 . Nilai $\mathrm{R}^{2}$ yang kecil berarti kemampuan variabel independen dalam menjelaskan variabel dependen sangat terbatas. Nilai yang mendekati 1 berarti variabel-variabel independen memberi hampir informasi yang dibutuhkan untuk memprediksi variabel dependen (Ghozali 2011 dalam Maulia 2015).

\section{b. Uji Statistik F}

Uji statistik $\mathrm{F}$ pada dasarnya menunjukkan apakah semua variabel independen yang dimasukkan dalam model mempunyai pengaruh bersama-sama terhadap dependen (Ghozali 2008 dalam Nudzunul 2015).

Adapun kriteria pengujian sercara parsial dengan tingkat level of significant $\alpha=5 \%$ yaitu sebagai berikut:

1) Jika p-value $>0,05$ maka Ho diterima, artinya variabel independen secara parsial tidak memiliki pengaruh signifikan terhadap dependen.

2) Jika p-value $<0,05$ maka Ho ditolak, artinya variabel independen secara parsial memiliki pengaruh signifikan terhadap dependen.

\section{c. Uji Statistik $\mathbf{t}$}

Menurut Fith (2015), pengujian hipotesis secara parsial merupakan suatu uji hipotesis untuk menguji pengaruh masing-masing variabel independen secara individual (parsial) terhadap variabel dependen. Untuk mengetahui variabel-variabel independen berpengaruh secara parsial terhadap variabel variabel dependen digunakan tingkat signifikan sebesar $\alpha=0,05$ atau 5\%. Hasil uji t pada SPSS dapat dilihat dari coeficient yang menunjukkan variabel independen secara individual berpengaruh terhadap variabel dependen jika p-value (pada kolom Sig) $\leq$ level of signifikan yang ditentukan. berikut:

Menurut Gusti 2013, pengujian statistik t dapat digunakan dengan cara sebagai

1. Membandingkan antara $t$ tabel dan $t$ hitung. Nilai t hitung dapat dicari dengan rumus (Ghozali, 2015): 


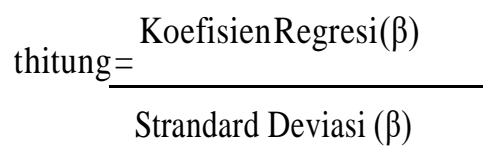

a. Bila $-\mathrm{t}$ tabel $<-\mathrm{t}$ hitung dan $\mathrm{t}$ hitung $<\mathrm{t}$ tabel, variabel bebas (independen) secara individu tidak berpengaruh terhadap variabel terikat (dependen).

b. Bila $t$ hitung $>t$ tabel dan $-t$ tabel $>-t$ hitung, variabel bebas (independen) secara individu berpengaruh terhadap variabel terikat (dependen).

\section{HASIL DAN PEMBAHASAN}

\section{Isi Hasil dan Pembahasan}

Uji Asumsi Klasik

Hasil uji normalitas dalam penelitian ini dapat dilihat dari tabel 4.2 sebagai berikut:

Tabel 4.2

\section{Hasil Uji Normalitas}

\begin{tabular}{|c|c|c|}
\hline & & $\begin{array}{l}\text { Unstandardized } \\
\text { Residual }\end{array}$ \\
\hline \multicolumn{2}{|l|}{$\mathrm{N}$} & 40 \\
\hline \multirow[t]{2}{*}{ Normal Parameters ${ }^{\mathrm{a}, \mathrm{b}}$} & $\begin{array}{l}\text { Mean } \\
\text { Std. Deviation }\end{array}$ & $\begin{array}{r}, 0000 \\
1.03050\end{array}$ \\
\hline & Absolute & 184 \\
\hline \multirow[t]{2}{*}{ Most Extreme Differences } & Positive & , 184 \\
\hline & Negative &,- 138 \\
\hline Kolmogorov-Smirnov Z & & 1,165 \\
\hline Asymp. Sig. (2-tailed) & & ,133 \\
\hline
\end{tabular}

Berdasarkan hasil pengujian normalitas yang dilakukan, dapat dilhat pada tabel 4.2 diatas bahwa jumlah data sebanyak 40 (empat puluh) data. Data memiliki berditribusi normal karena nilai Kolmogorov-Smirnov tersebut memiliki tingkat signifikansi 0,131 lebih besar dari 0,05.

Hasil uji yang dilakukan dengan menggunakan normalitas dari model regresi dalam penelitian ini dapat dilihat pada gambar dibawah ini: 
Histogram

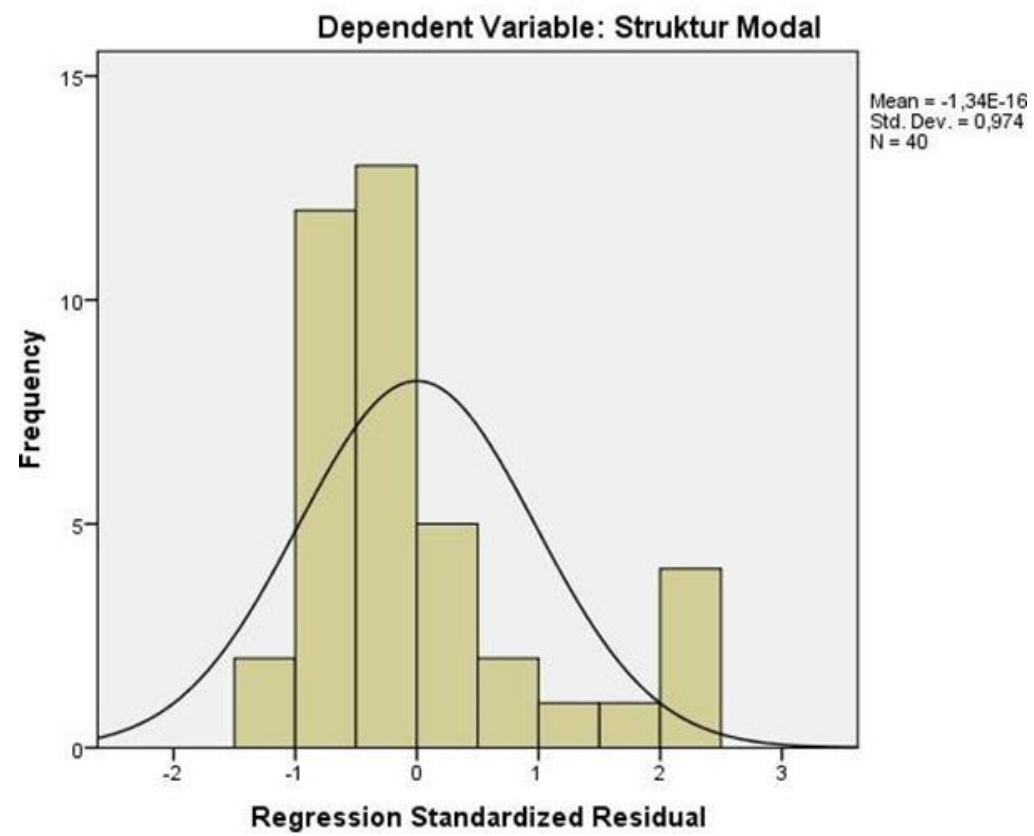

\section{Gambar 4.1 Hasil Uji Normalitas}

\section{Normal P-P Plot of Regression Standardized Residual}

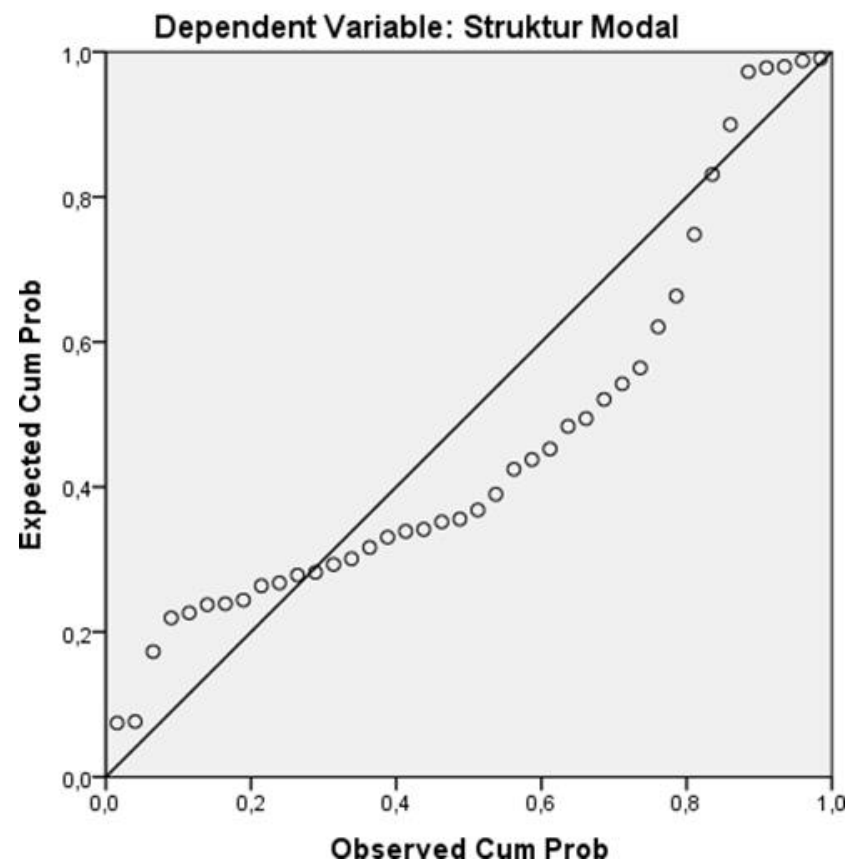

Pada Gambar 4.1 dapat dilihat dari grafik histogram tersebut bahwa bentuk grafik mengikuti pola garis terbentuk, dapat disimpulkan data terdistribusi normal. Pada Gambar 4.2 dari plot data menunjukkan bahwa kurva penyebaran p-plot titik-titik menyebar disekitar garis diagonal dan mengikuti arah garis diagonal, maka model regresi memenuhi asumsi normalitas data. 


\section{b. Uji Multikolinearitas}

Menurut Nudzunul 2015 uji multikoliniearitas bertujuan untuk menguji apakah dalam persamaan regresi ditemukan adanya korelasi antar variabel independen. Variabel yang menyebabkan multikolinearitas dapat diketahui dengan melihat nilai tolerance yang lebih kecil dari 0,1 atau nilai Variance Inflation Factor (VIP) yang besar dari 10. Hasil dari uji multikoliniearitas pada penelitian ini terlihat pada tabel berikut:

Tabel 4.3

Hasil Uji Multikoliniearitas Coefficients ${ }^{a}$

\begin{tabular}{|c|l|c|c|}
\hline \multicolumn{2}{|c|}{ Model } & \multicolumn{2}{c|}{ Collinearity Statistics } \\
\cline { 3 - 4 } & Tolerance & VIF \\
\hline \multirow{2}{*}{1} & (Constant) & & \\
& Struktur Aktiva &, 942 & 1,062 \\
& Pertumbuhan Penjualan &, 942 & 1,062 \\
\hline
\end{tabular}

a. Dependent Variable: Struktur Modal

Dari tabel 4.3 dapat dilihat bahwa nilai tolerance variabel struktur aktiva dan pertumbuhan penjualan adalah 0,942. Nilai VIF variabel struktur aktiva dan pertumbuhan penjualan adalah 1,062. Berdasarkan nilai tolerance untuk semua variabel lebih besar dari 0,1 (tolerance $\geq 0,1$ ) dan nilai VIF lebih kecil dari 10 (VIF $\leq 10$ ), maka dapat disimpulkan bahwa struktur aktiva dan pertumbuhan penjualan tidak terjadi multikolinearitas.

\section{c. Uji Autokorelasi}

Uji autokorelasi bertujuan untuk menguji apakah dalam model linear dan korelasi antara kesalahan pengangguran pada periode t dengan kesalahan penganggu pada t-1 (sebelumnya). Hasil pengujian autokorelasi pada penelitian dapat disajikan pada tabel dibawah ini:

\section{Tabel 4.4 \\ Hasil Uji Autokorelasi Model Summary ${ }^{b}$}

\begin{tabular}{|c|c|r|r|r|r|}
\hline Model & $\mathrm{R}$ & $\begin{array}{c}\mathrm{R} \\
\text { Square }\end{array}$ & $\begin{array}{c}\text { Adjusted R } \\
\text { Square }\end{array}$ & $\begin{array}{c}\text { Std. Error of } \\
\text { the Estimate }\end{array}$ & $\begin{array}{c}\text { Durbin- } \\
\text { Watson }\end{array}$ \\
\hline 1 &, $401^{\mathrm{a}}$ &, 161 &, 115 & 1,0579824 &, 606 \\
\hline
\end{tabular}

a. Predictors: (Constant), Pertumbuhan Penjualan, Struktur Aktiva

b. Dependent Variable: Struktur Modal

Dari tabel 4.4 menunujukkan bahwa uji Durbin-Watson sebesar 0,606. Oleh karena nilai DW di antara -2 sampai +2 maka dapat disimpulkan bahwa tidak mengalami gejala autokorelasi.

\section{d. Uji Heteroskedastisitas}

Menurut Nudzunul (2015), uji ini digunakan untuk menguji model regresi apakah ada 
ketidaksamaan varians dari residual satu pengamatan ke pengamatan lain, Heteroskedastisitas muncul karena adanya residual dari model yang diamati tidak memiliki varians yang konstan dari observasi satu ke observasi lainnya. Hasil uji heteroskedastisitas pada penelitian dapat lihat pada tabel 4.5 sebagai berikut:

Tabel 4.5

\section{Heteroskedastisitas}

\begin{tabular}{|c|c|c|c|c|c|}
\hline \multirow{2}{*}{ Model } & \multicolumn{2}{|c|}{$\begin{array}{c}\text { Unstandardized } \\
\text { Coefficients }\end{array}$} & $\begin{array}{r}\text { Standardized } \\
\text { Coefficients }\end{array}$ & \multirow{2}{*}{$\mathrm{T}$} & Sig. \\
\cline { 2 - 4 } & B & $\begin{array}{r}\text { Std. } \\
\text { Error }\end{array}$ & Beta & & \\
\hline $\begin{array}{c}\text { (Constant) } \\
\text { Struktur }\end{array}$ & $-4,968 \mathrm{E}-016$ &, 307 & &, 000 & 1,000 \\
$\begin{array}{c}1 \text { Aktiva } \\
\text { Pertumbuhan } \\
\text { Penjualan }\end{array}$ &, 000 &, 909 &, 000 &, 000 & 1,000 \\
\hline
\end{tabular}

Dependent Variable: Abresid

Dari data tabel 4.5 diatas dapat dilihat bahwa probabilitas atau taraf signifikansi masingmasing variabel 1,000 sehingga dapat dipastikan bahwa model tersebut tidak mengalami gejala heteroskedastisitas, dengan kata lain bahwa korelasi masing-masing variabel dengan nilai residunya menghasilkan nilai yang lebih besar dari alpha-nya $(0,05)$.

Hasil uji heteroskedastisitas dalam penelitian ini dapat dilihat pada gambar dibawah ini: 


\section{Gambar 4.3}

Hasil Uji Heteroskedatisitas

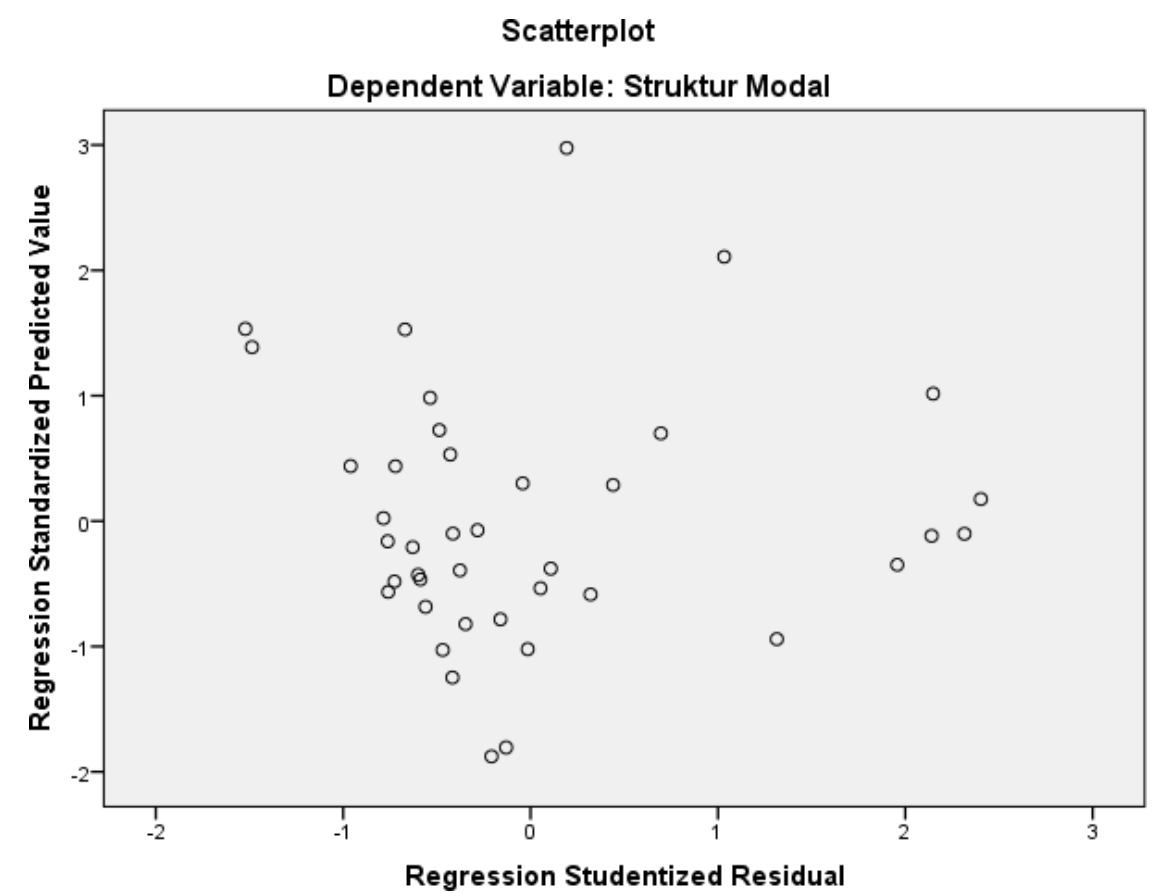

Berdasarkan gambar 4.3 dapat diperoleh bahwa scatterplot membentuk titik-titik yang menyebar secara acak dengan tidak membentuk pola yang jelas, serta sudah tersebar baik diatas maupun dibawah angka nol pada sumbu Y. Hal ini menunjukkan bahwa tidak terjadi gejala heteroskedastisitas.

\section{Model Regresi Berganda}

Menurut Syofian Siregar (2013:301), Regresi berganda adalah pengembangan dari regresi linier sederhana, yaitu sama-sama alat yang digunakan untuk memprediksi permintaan di masa akan datang berdasarkan data masa lalu atau untuk mengetahui pengaruh satu atau lebih variabel bebas terhadap satu variabel tak bebas yang digunakan. Berikut ini adalah hasil uji dari analisis regresi berganda:

Tabel 4.6

Hasil Uji Regresi Berganda

Coefficients $^{a}$

\begin{tabular}{|c|c|c|c|c|c|}
\hline \multirow{2}{*}{ Model } & \multicolumn{2}{|c|}{$\begin{array}{c}\text { Unstandardized } \\
\text { Coefficients }\end{array}$} & $\begin{array}{c}\text { Standardized } \\
\text { Coefficients }\end{array}$ & $\mathrm{t}$ & Sig. \\
\cline { 2 - 5 } & $\mathrm{B}$ & Std. Error & Beta & & \\
\hline \multirow{2}{*}{$\begin{array}{l}\text { (Constant) } \\
\text { Struktur Aktiva }\end{array}$} &,- 923 &, 909 &,- 157 & $-1,014$ &, 317 \\
$\begin{array}{l}\text { Pertumbuhan } \\
\text { Penjualan }\end{array}$ & 1,590 &, 742 &, 333 & 2,144 &, 039 \\
\hline
\end{tabular}


Dari tabel 4.6 diatas maka diperoleh persamaan regresi berganda sebagai berikut:

$\mathrm{Y}=\mathrm{a}+\mathrm{b}_{1} \mathrm{X}_{1}+\mathrm{b}_{2} \mathrm{X}_{2}$

$Y=1,476-0,923 X_{1}+1,590 X_{2}$

Keterangan :

$\mathrm{Y}=$ Struktur Modal

$\mathrm{X}_{1}=$ Struktur Aktiva

$\mathrm{X}_{2}=$ Pertumbuhan Penjualan

\section{a. Pengujian Hipotesis}

\section{Uji Koefisien Determinasi $\left(\mathbf{R}^{2}\right)$}

Koefisien determinasi pada intinya untuk mengatur seberapa jauh kemampuan model dalam menerangkan variasi variabel dependen (Ghozali 2011 dalam Maulia 2015). Hasil uji koefisien determinasi $\left(\mathrm{R}^{2}\right)$ dapat dilihat pada tabel dibawah ini:

Tabel 4.7

Hasil Uji Koefisien Determinasi $\left(\mathbf{R}^{2}\right)$

\begin{tabular}{|l|l|l|l|r|}
\hline Model & $\mathrm{R}$ & R Square & $\begin{array}{c}\text { Adjusted R } \\
\text { Square }\end{array}$ & $\begin{array}{c}\text { Std. Error of } \\
\text { the Estimate }\end{array}$ \\
\hline 1 &, $401^{\mathrm{a}}$ &, 161 &, 115 & 1,0579824 \\
\hline
\end{tabular}

1. Predictors: (Constant), Pertumbuhan Penjualan, Struktur Aktiva

2. Dependent Variable: Struktur Modal

Dari tabel 4.7 dapat dilihat nilai koefisien determinasi (Adjusted $R$ Square) sebesar 0,115 atau $11,5 \%$ dari variabel struktur modal dapat dijelaskan atau dipengaruhi oleh struktur aktiva dan pertumbuhan penjualan. Sedangkan sisanya $88,5 \%$ dijelaskan atau dipengaruhi oleh variabelvariabel yang lain, presentase ini cukup tinggi

\section{Uji Secara Simultan (Uji F)}

Uji F menunjukkan apakah semua variabel independen yang dimasukkan dalam model mempunyai pengaruh bersama-sama terhadap dependen (Ghozali 2008 dalam Nudzunul 2015). Hasil uji F dapat dilihat pada tabel dibawah ini:

Tabel 4.8 Uji F

ANOVA $^{\mathrm{a}}$

\begin{tabular}{|l|c|c|c|c|c|}
\hline Model & $\begin{array}{c}\text { Sum of } \\
\text { Squares }\end{array}$ & Df & $\begin{array}{c}\text { Mean } \\
\text { Square }\end{array}$ & F & Sig. \\
\hline Regression & 7,935 & 2 & 3,968 & 3,545 &, $039^{\mathrm{b}}$ \\
1 Residual & 41,415 & 37 & 1,119 & & \\
Total & 49,350 & 39 & & & \\
\hline
\end{tabular}

1. Dependent Variable: Struktur Modal 
2. Predictors: (Constant), Pertumbuhan Penjualan, Struktur Aktiva

Berdasarkan tabel 4.8 diatas, hasil ANOVA atau Uji F menunjukkan bahwa nilai regresi memiliki signifikansi 0,039 , nilai lebih kecil dari 0.05 atau nilai signifikan $<\alpha$ sehingga $\mathrm{Ho}_{3}$ ditolak dan $\mathrm{Ha}_{3}$ diterima yang artinya terdapat pengaruh secara bersama- sama (simultan) signifikan antara struktur aktiva dan pertumbuhan penjualan terhadap struktur modal.

\section{Uji Secara Parsial (Uji t)}

Menurut Fith (2015), pengujian hipotesis secara parsial merupakan suatu uji hipotesis untuk menguji pengaruh masing- masing variabel independen secara individual (parsial) terhadap variabel dependen. Hasil uji t dapat dilihat pada tabel dibawah ini:

\section{Tabel 4.9}

\section{Hasil Uji t}

\begin{tabular}{|c|c|c|c|c|c|}
\hline \multirow{2}{*}{ Model } & \multicolumn{2}{|c|}{$\begin{array}{c}\text { Unstandardized } \\
\text { Coefficients }\end{array}$} & $\begin{array}{c}\text { Standardized } \\
\text { Coefficients }\end{array}$ & \multirow{2}{*}{$\mathrm{T}$} & \multirow{2}{*}{ Sig. } \\
\hline & B & $\begin{array}{l}\text { Std. } \\
\text { Error }\end{array}$ & Beta & & \\
\hline \multirow{4}{*}{$\begin{array}{l}\text { (Constant) } \\
\text { Struktur } \\
1 \text { Aktiva } \\
\text { Pertumbuhan Penjualan }\end{array}$} & 1,476 & ,307 & & 4,803 & ,000 \\
\hline &,- 923 & ,909 &,- 157 & $-1,014$ & ,317 \\
\hline & & & & $0+4$ & Pon \\
\hline & 1,590 & ,742 & ,333 & 2,144 & 039, \\
\hline
\end{tabular}

\section{a. Dependent Variable: Struktur Modal}

Dari tabel 4.9 diatas dapat diketahui bahwa struktur aktiva memiliki $t_{\text {hitung }}$ sebesar $-1,014$ dengan signifikansi 0,317 lebih besar dengan tingkat signifikansi 0,05 maka $\mathrm{Ho}_{1}$ diterima dan $\mathrm{Ha}_{1}$ ditolak sehingga dapat disimpulkan bahwa struktur aktiva secara parsial tidak berpengaruh secara signifikan terhadap struktur modal.

Dari tabel 4.9 diatas dapat diketahui bahwa pertumbuhan penjualan memiliki $t_{\text {hitung }}$ sebesar 2,144 dengan signifikansi 0,039 lebih kecil dengan tingkat signifikansi 0,05 maka $\mathrm{Ho}_{2}$ ditolak dan $\mathrm{Ha}_{2}$ diterima sehingga dapat disimpulkan bahwa pertumbuhan penjualan secara parsial berpengaruh signifikan terhadap struktur modal.

\section{PEMBAHASAN}

a. Pengaruh Struktur Aktiva terhadap Struktur Modal

Berdasarkan hasil penelitian yang telah diuraikan secara statistik dengan menggunakan program SPSS maka dapat dilihat bahwa struktur aktiva memiliki $t_{\text {hitung }}$ sebesar -1,014 dengan signifikansi 0,317 lebih besar dengan taraf signifikansi 0,05 maka $\mathrm{Ho}_{1}$ diterima dan $\mathrm{Ha}_{1}$ ditolak. Sehingga dapat disimpulkan bahwa struktur aktiva secara parsial tidak berpengaruh secara signifikan terhadap struktur modal. Hasil penelitian terdahulu yang konsisten dengan penelitian ini yaitu Rista Bagus Sartika dan Bambang Sudiyatno (2011); Syafrida Hani, Dilla Ainur Rahmi (2014) dan Yorena Alfian Alib, Bambang Suryono (2014). Berdasarkan penelitian terdahulu yang sampel dan pengamatan yang beda, yang sama mengatakan bahwa struktur aktiva tidak berpengaruh terhadap struktur modal.

b. Pengaruh Pertumbuhan Penjualan terhadap Struktur Modal

Berdasarkan hasil penelitian yang telah diuraikan secara statistik dengan menggunakan program SPSS maka dapat dilihat bahwa pertumbuhan penjualan memiliki $t_{\text {hitung }}$ sebesar 2,144 dengan signifikansi 0,039 lebih kecil dengan tingkat signifikansi 0,05 maka Ho2 ditolak dan $\mathrm{Ha}_{2}$ diterima. Sehingga dapat disimpulkan bahwa pertumbuhan penjualan secara parsial 
berpengaruh signifikan terhadap struktur modal. Hasil penelitian terdahulu yang konsisten dengan penelitian ini yaitu Rista Bagus Sartika dan Bambang Sudiyatno (2011); Sarsa Meta Nugrahani, R. Djoko Sampurno (2012) dan Ida Ayu Dewi Kusuma Wardani, Wayan Cipta, I Wayan Suwendra (2016). Berdasarkan penelitian terdahulu yang sampel dan pengamatan yang beda, yang sama mengatakan bahwa pertumbuhan penjualan berpengaruh terhadap struktur modal.

\section{c. Pengaruh Struktur Aktiva dan Pertumbuhan Penjualan terhadap Struktur Modal}

Berdasarkan hasil penelitian yang telah diuraikan secara statistik dengan menggunakan program SPSS maka dapat dilihat bahwa nilai regresi memiliki signifikansi 0,039, nilai lebih kecil dari 0,05 atau nilai signifikan $<\alpha$ sehingga $\mathrm{Ho}_{3}$ ditolak dan $\mathrm{Ha}_{3}$ diterima yang artinya terdapat pengaruh secara bersama-sama (simultan) signifikan antara struktur aktiva dan pertumbuhan penjualan terhadap struktur modal. Hasil penelitian terdahulu yang konsisten dengan penelitian ini yaitu yaitu Rista Bagus Sartika dan Bambang Sudiyatno (2011); Yorena Alfian Alib, Bambang Suryono (2014) dan Maulia Habibah (2015). Berdasarkan penelitian terdahulu yang sampel dan pengamatan yang beda, yang sama mengatakan bahwa struktur aktiva dan pertumbuhan penjualan berpengaruh terhadap struktur modal.

\section{SIMPULAN}

1. Secara parsial, struktur aktiva tidak berpengaruh secara signifikan terhadap struktur modal pada perusahaan pertambangan yang terdaftar di Bursa Efek Indonesia periode 2014-2018. Hal ini dibuktikan bahwa struktur aktiva memiliki $t_{\text {hitung }}$ sebesar -1,014 dengan signifikansi

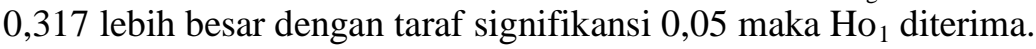

2. Secara parsial, pertumbuhan penjualan berpengaruh secara signifikan terhadap struktur modal pada perusahaan pertambangan yang terdaftar di Bursa Efek Indonesia periode 20142018. Hal ini dibuktikan bahwa pertumbuhan memiliki $t_{\text {hitung }}$ sebesar 2,144 dengan signifikansi 0,039 lebih kecil dengan taraf signifikansi 0,05 maka $\mathrm{Ha}_{2}$ diterima.

3. Secara simultan, pengaruh struktur aktiva dan pertumbuhan penjualan terhadap struktur modal pada perusahaan pertambangan yang terdaftar di Bursa Efek Indonesia periode 2014-2018. Hal ini dibuktikan bahwa nilai regresi memiliki tingkat signifikansi 0,039 lebih kecil dari 0,05 maka $\mathrm{Ha}_{3}$ diterima.

\section{DAFTAR PUSTAKA}

Alib, Yoreno Alfian \& Bambang Suryono. 2014. Pengaruh Struktur Aset, Profitabilitas, Growth dan Size tehadap Struktur Modal pada Perusahaan Otomotif. Jurnal Ilmu \& Riset Akuntansi, Vol. 3, No. 1.

Dewani, Trisna Hayuning. 2010. Analisis Faktor-Faktor yang Mempengaruhi Struktur Modal. Skripsi. Semarang : Universitas Diponegoro.

Habibiah, Maulia. 2015. Analisis Pengaruh Profitabilitas, Struktur Aset, Likuiditas dan Pertumbuhan Penjualan terhadap Struktur Modal. Jurnal Ilmu \& Riset Akuntansi, Vol. 4, No. 7.

Hani, Syarida \& Dilla Ainur Rahmi. 2014. Analisis Pertumbuhan Penjualan dan Struktur Aktiva terhadap Struktur Perdanaan Eksternal. Jurnal Manajemen \& Bisnis, Vol. 14, No. 01, April 2014, ISSN 1693-7619.

Haryoputra, Herdjuno Bagus. 2012. Analisis Faktor-Faktor yang Mempengaruhi Struktur Modal pada Perusahaan Manufaktur yang Terdaftar di Bursa Efek Indonesia Periode 2006-2010. Skripsi. Semarang : Universitas Diponegoro.

Husnan, Suad. 2009. Manajemen Keuangan. Jakarta : Universitas Terbuka. Ichwan, Fith Yuniar \& Dini Widyawati. 2015. Pengaruh Ukuran Perusahaan,

Struktur Aktiva dan Profitabilitas terhadap Struktur Modal. Jurnal Ilmu \& Riset Akuntansi, Vol. 4, No. 6. 
Juliwati. 2015. Analisis Faktor-Faktor yang Mempengaruhi Struktur Modal pada Perusahaan Manufaktur Sektor Aneka Industri yang Terdaftar di Bursa Efek Indonesia Periode 2011-2014. Skripsi. Batam : Gici Business School.

Kamsir. 2015. Analisis Laporan Keuangan. Jakarta : Rajawali Pers.

Nugrahani, Sarsa Meta \& R. Djoko Sampurno. 2012. Analisis Pengaruh Profitabilitas, Likuiditas, Pertumbuhan Penjualan, Ukuran Perusahaan, dan Kepemilikan Manajerial terhadap Struktur Modal. Jurnal Bisnis dan Akuntansi, Vol. 1, No. 1, Tahun 2012, Hlm.1-9.

Santika, Rista Bagus \& Bambang Sudiyatno. 2011. Menentukan Struktur Modal Perusahaan Manufaktur di Bursa Efek Indonesia. Dinamika Keuangan dan Perbankan, Vol. 3, No. 2, Nopember 2011, Hal. 172-182, ISSN 19794878.

Sarasati, Gusti. 2013. Analisis Pengaruh Profitabilitas, Price Earning Ratio, Struktur Aktiva, Operating Leverage, dan Pertumbuhan Penjualan terhadap Struktut Modal. Skripsi. Semarang : Universitas Diponegoro.

Siregar, Syofian. 2013. Metode Penelitian Kuantitatif dengan Perbandingan Perhitungan Manual \& SPSS. Jakarta : Kencana.

Thausyah, Nudzunul Fiara \& Suwitho. 2015. Pengaruh Pertumbuhan Penjualan, Struktur Aktiva dan Profitabilitas terhadap Struktur Modal. Jurnal Ilmu dan Riset Manajemen, Vol. 4, No. 9, Agustus 2015.

Wardani, Ida Ayu Dewi Kusuma, dkk. 2016. Pengaruh Ukuran Pertumbuhan, Pertumbuhan Penjualan, dan Profitabilitas terhadap Struktur Modal pada Perusahaan Manufaktur. Jurusan Manajemen, Vol. 4, Tahun 2016. 